\title{
Teaching the Unthinkable: \\ Counter-Narratives, Pedagogy, and Genocide
}

\author{
Stephanie Schneider ${ }^{1}$
}

This study focuses on the pedagogy of teaching about the Armenian Genocide and the Holocaust by using alternate texts to create a counter-narrative. By using different genres, teachers can encourage students to question the dominant historical narratives about the Armenian Genocide and Holocaust. Alternate texts include poetry, graphic novels, plays, and films. Each of these genres invites the reader or viewer to actively engage in history by examining the viewpoint of the victims of genocide. School curriculums must change so that future generations will have a more complete understanding of genocide. [Article copies available for a fee from The Transformative Studies Institute. E-mail address: journal@transformativestudies.org Website: http://www.transformativestudies.org (C2014 by The Transformative Studies Institute. All rights reserved.]

KEYWORDS: Pedagogy, Poetry, Literacy Studies, Genocide, History.

Cato the Elder, a Roman statesman ended every one of his speeches with the words "Carthago delenda est" or "Carthage must be destroyed". These speech acts helped to foist Rome into the Third Punic War. This war resulted in the evisceration of Carthage. Salt was sown into the soil so no crops grew again. The population was eradicated, and Carthage as a civilization perished. Yet, in the West, we hold Rome up as a bastion of Republican ideals. It is not hard to make the leap from Cato's speeches to the speeches we see in the most reviled regimes seeking to destroy a population. The Rwandan radio that called Tutsis "cockroaches" that must be squashed to the Nazis who called Jews "rats" who should be

\footnotetext{
${ }^{1}$ Stephanie Schneider, Ph.D. holds a Doctorate in Literacy Studies. She currently teaches in the School of Education at the State University of New York College at Old Westbury. Prior to this, Dr. Schneider taught special education and social studies at Herricks High School in Long Island, New York. She is currently working on pedagogical practices through the use of poetry, as well as interdisciplinary instructional strategies. Address correspondence to: Stephanie Schneider, e-mail: schneiders@oldwestbury.edu.
}

1937-0229 (C2014 Transformative Studies Institute 